\title{
BANKING, BUSINESS, AND CONTRACT LAW
}

\author{
Frank Sullivan, JR., ${ }^{* * *}$
}

This Article surveys banking, business, and contract law decisions of the Indiana Supreme Court and Indiana Court of Appeals between September 1, 2013, and August 31, 2014. This Article includes discussion of many so-called not-for-publication "memorandum" decisions of the court of appeals because such decisions often establish new law; clarify, modify, or criticize existing law; or involve legal or factual issues of unique interest or substantial public importance. Whatever the appellate rules are at the moment about the citation of memorandum decisions, they contain critical guidance on Indiana law and cannot be ignored. ${ }^{1}$

This Article will not itemize every banking, business, and contract law case decided during the survey period. Instead, it will highlight cases illustrating some of the big-picture issues in these fields as well as some practice pointers for both transactions lawyers and litigators. This Article will also discuss the Indiana Supreme Court's commercial courts initiative and the enactment of a new statute authorizing "benefit corporations."

\section{Commercial Courts Come to Indiana}

For many decades now, the Delaware Court of Chancery has enjoyed an exalted reputation for the manner in which it has adjudicated business disputes, especially those over corporate governance. ${ }^{2}$ Major national corporations explicitly attribute their decisions to incorporate in Delaware to the "prominence and predictability of Delaware corporate law." ${ }^{3}$

In today's competitive economic development environment and in a push for judicial efficiency, at least twenty-seven states have established specialized business or complex litigation courts to assure judicial expertise and streamline business litigation. ${ }^{4}$

* Professor of Practice, Indiana University Robert H. McKinney School of Law. Justice, Indiana Supreme Court (1993-2012). LL.M., University of Virginia School of Law (2001); J.D., Indiana University Maurer School of Law (1982); A.B., Dartmouth College (1972).

** This Article is adapted from remarks delivered on September 16, 2015, at the Annual Indiana Law Update CLE program organized by Judges Margret G. Robb and Cale J. Bradford. I thank Judges Robb and Bradford for including me in this distinguished CLE program. I also thank Ladene Mendoza and Michelle Swinney for their research and editing assistance in connection with this Article.

1. Indiana Appellate Rule 65 provides decisions of the Indiana Court of Appeals that are not published in West's Northeastern Reporter "shall not be regarded as precedent and shall not be cited to any court except by the parties to the case to establish res judicata, collateral estoppel, or law of the case." IND. R. APP. P. 65.

2. E. Norman Veasey, An Economic Rationale for Judicial Decisionmaking in Corporate Law, 53 Bus. LAW. 681, 682 (1998).

3. $I d$. at 683 (citing Hewlett Packard Co., 1998 Proxy Statement 22-24).

4. Richard L. Renck \& CARmen Thomas, The Nationwide InNovation OF Specialized Business AND COMmercial Courts for EfFective Resolution of Business Disputes: 
Commercial court case management typically involves the parties' attorneys in developing and implementing an effective case management plan; anticipating problems before they arise; requiring periodic status conferences and joint status reports; and judicial availability for hearings on short notice. The overarching idea is that commercial litigation is resolved much more efficiently and effectively when the cases are segregated onto a dedicated docket presided over by specially trained judges with expertise in the subject matter. ${ }^{5}$

During the survey period, the Indiana Supreme Court took a special interest in establishing such courts here in Indiana. ${ }^{6}$ In June 2015, the court constituted a "working group" to recommend guidelines for establishing and administering commercial courts in our state. ${ }^{7}$ Judge Craig J. Bobay of the Allen Superior Court was designated to serve as chair. ${ }^{8}$

This working group of approximately two dozen individuals from throughout the state included judges, practicing lawyers, two state legislators, the author, and Kevin Brinegar, President and CEO of the Indiana Chamber of Commerce. ${ }^{9}$ In three, day-long meetings during the summer of 2015, the working group developed a detailed recommendation for the court. ${ }^{10}$ Six judges from the working group actively participated: Judge Bobay; Judge Stephen R. Bowers (Elkhart Superior Court); Judge Maria D. Granger (Floyd Superior Court); Judge John M. Sedia (Lake Superior Court); Judge Heather A. Welch (Marion Superior Court); and Judge Richard G. D'Amour (Vanderburgh Superior Court). ${ }^{11}$

On October 29, 2015, Indiana Chief Justice Loretta H. Rush wrote the working group, thanking it for its report, and saying the court was "unanimously in favor of moving forward with establishing a Commercial Court Pilot Project in Indiana as proposed." 12 In her State of the Judiciary speech on January 13, 2016, Chief Justice Rush announced, "[t]his year, our first six commercial courts will start hearing cases." 13

SumMary OF RESOURCES AND COURTS (2014).

5. IND. COMMERCIAL COURT WORKING GRP., INITIAL REPORT OF THE INDIANA COMMERCIAL COURT Working Group to the Indiana Supreme Court 6 (Sept. 30, 2015) (copy on file with author) [hereinafter INITIAL REPORT].

6. During the survey period, the court studied the use of commercial and business courts throughout the country and explicitly concluded that establishing commercial courts in Indiana is in the best interest of the state. Order Establishing the Indiana Commercial Court Working Group, No. 94S00-1506-MS-337, 2015 Ind. LEXIS 466 (Ind. June 2, 2015).

7. $I d$.

8. $I d$.

9. $I d$.

10. INITIAL REPORT, supra note 5.

11. Id.

12. Letter dated October 29, 2015, from Chief Justice Loretta H. Rush to the Indiana Commercial Courts Working Group (copy on file with author).

13. Chief Justice Loretta H. Rush, A Constitution Powerful in its Simplicity, Clear in its Mandate (January 13, 2016) (http://www.in.gov/judiciary/supreme/2505.htm) (last visited May 30, 2016). 
On January 20, 2016, the Indiana Supreme Court formally created the Indiana Commercial Court Pilot Project to commence on June 1, 2016, for a term not to exceed three years. ${ }^{14}$ The court ordered the six judges named above to participate in the pilot project. ${ }^{15}$ The court also ordered the previouslyestablished working group to provide guidance throughout the pilot project and the pilot project to operate pursuant to guidelines adopted by the working group addressing case eligibility, assignment, and transfer; caseload and workload; commercial court masters; the publication of commercial court orders and statistics; and other relevant matters. The working group is also to provide biannual updates to the court on the guidelines.

On April 27, 2016, the Indiana Supreme Court adopted Interim Commercial Court Rules for the pilot project, addressing the eligibility and assignment of cases to the commercial court docket and other matters. ${ }^{16}$

The interim rules provide any civil case filed in a pilot county (including jury and non-jury cases; cases seeking injunctions, TROs, and declaratory judgments; and derivative actions) would be eligible for assignment to a "Commercial Docket" if the gravamen of the case relates to any of the following:

- Business entity formation, dissolution, and governance issues;

- Disputes between and among the owners, directors, and other constituents of a business entity as to their respective rights and obligations, including liability and indemnity to or from the business entity;

- Trade secret, non-disclosure, non-compete, and employment agreements involving a business entity;

- Disputes between and among two or more business entities or individuals as to their business activities relating to contracts, transactions, or relationships between or among them; and

- Cases otherwise falling within the general intended purpose of the Commercial Docket subject to the acceptance of jurisdiction by the Commercial Court Judge. ${ }^{17}$

Excluded are a long list of matters the working group concluded either were not appropriate for the Commercial Docket or were so voluminous they would clog the Commercial Docket to the choking point. Among the exclusions are personal injury cases, domestic relations cases, and small claims. ${ }^{18}$

The interim rules require all parties to an eligible case consent to the Commercial Docket. ${ }^{19}$ That is, the interim rules provide for an entirely voluntary

14. Order Establishing the Indiana Commercial Court Pilot Project, No. 94S00-1601-MS-31, 2016 Ind. LEXIS 29 (Ind. Jan. 20, 2016).

15. Id.

16. Order Adopting Interim Commercial Court Rules for the Indiana Commercial Courts Pilot Project, No. 94S00-1601-MS-31, 2016 Ind. LEXIS 308 (Ind. Apr. 27, 2016).

17. Id. (IND. COMM. CT. INTERIM R. 2).

18. Id. (IND. COMM. CT. INTERIM R. 3).

19. Id. (IND. COMM. CT. INTERIM R. 4). 
system; if a party does not want its case to be on the Commercial Docket, the party would have it within its power to keep it off. ${ }^{20}$ On the other hand, if a party wants its case to be on the Commercial Docket, it will require the acquiescence of all other parties in the case. ${ }^{21}$

That said, the interim rules are structured with the defaults placing an eligible case on the Commercial Docket. ${ }^{22}$ For example, if a party filing a case designates it for the Commercial Docket, it will be placed on the Commercial Docket unless another party opts out within a specified period of time. ${ }^{23}$

The pilot project was launched on schedule on June 1, 2016, to a warm welcome from the Indiana business community. ${ }^{24}$

\section{LENDING AND BORROWING}

The mandate of this Article includes "banking" and the author includes within that meaning litigation between lenders and borrowers.

Wells Fargo Bank v. Rieth-Riley Construction $\mathrm{Co}^{25}$ is a really interesting mechanic's lien case. Rieth-Riley Construction Company was not paid for paving a parking lot at a shopping center on which Wells Fargo held the first mortgage. ${ }^{26}$ Rieth-Riley sought to foreclose its mechanic's lien and joined Wells Fargo. ${ }^{27}$

Rieth-Riley argued its mechanic's lien had priority over the first mortgage. ${ }^{28}$ The court rejected that argument, instead finding that "Indiana Courts have long held that a mortgage lien was superior to a mechanic's lien if the mortgage was recorded before the mechanic's work was begun or materials furnished." ${ }^{29}$ Here, Wells Fargo's mortgage predated the commencement of Rieth-Riley's work by many years. ${ }^{30}$

However, and here is where the case gets interesting, the court acknowledged the mechanic's lien statute provided Rieth-Riley priority as to any improvements it had made and could assert this priority to the extent it was able to remove and sell these improvements. ${ }^{31}$

Rieth-Riley's response was since that was so, it was entitled to scrape the asphalt off the parking lot and sell it! ${ }^{32}$ Wells-Fargo did not take too kindly to that idea but the court held, to the extent that removal of the asphalt was practical, it

20. Id. (IND. COMM. CT. INTERIM R. 4(B)).

21. Id. (IND. Comm. Ct. Interim R. 4(D)(3), (E)(3), and (F)(3)).

22. Id. (IND. COMM. CT. INTERIM R. 4 cmt. 4).

23. Id. (Ind. COMm. Ct. InTERIm R. 4(D)(2)).

24. See Tom Schuman, Court(ing) Business: Complex Cases to Receive Clear Focus, 19 BizVoice 14 (May/June 2016).

25. 38 N.E.3d 666 (Ind. Ct. App. 2015).

26. Id. at 668 .

27. Id.

28. Id.

29. Id. at 671 (internal quotations omitted).

30. Id.

31. Id.

32. Id. at 673 . 
fell within the category of things the mechanic's lien statute allows to be removed to satisfy a mechanic's lien. ${ }^{33}$

The author submits that Rieth-Riley's lawyers did a good job here. By threatening to remove the asphalt from the parking lot and pressing the point in court, they likely got Wells Fargo's attention and probably some type of settlement. This would have been fair since Wells Fargo's collateral-the shopping center - in all likelihood benefited from having a freshly paved parking lot.

\section{A. Mortgagors Make a Comeback}

In previous surveys, lenders prevailed in cases seeking recovery of their collateral and mortgagors were shut out. ${ }^{34}$ Many cases like that arose during this survey period, of course, but there were also a number of cases in which mortgagors prevailed, at least in part. ${ }^{35}$

In Hair v. Deutsche Bank, Deutsche Bank foreclosed on property with respect to which Calvin Hair was a judgment lienholder of record. ${ }^{36}$ The bank served Hair with notice of the lawsuit by publication only. ${ }^{37}$ The trial court entered judgment by default against Hair and others who had not responded to the bank's complaint. ${ }^{38}$

The court reversed, holding the bank's foreclosure judgment was void as to Hair, and Hair's judgment lien against the property was not extinguished. ${ }^{39}$ In doing so, the court rejected with high dudgeon the bank's argument that setting aside the foreclosure would be a waste of judicial resources because there would have been insufficient proceeds to satisfy Hair's lien. ${ }^{40}$ The bank's "arguments disregard[ed] the importance of personal jurisdiction to a valid judgment, as well as approximately 150 years of Indiana precedent." ${ }^{41}$

In Good v. Wells Fargo, Wells Fargo foreclosed on a mortgage executed by Bryan Good to secure a promissory note. ${ }^{42}$ The note was an electronic promissory note which provided in part that the only copy would be "the authoritative copy ... that is within the control of the person identified as the Note Holder in the Note Holder Registry (or that person's designee)." ${ }^{43}$

The court engaged in a very close reading of UCC Article 3 (negotiable instruments) and 15 U.S.C. $§ 7021$ concerning electronic records and concluded,

33. Id. at 673-75.

34. See generally Frank Sullivan, Jr., Banking, Business, and Contract Law, 48 IND. L. Rev. 1195 (2015).

35. $I d$

36. Hair v. Deutsche Bank Nat'1 Trust Co., 18 N.E.3d 1019, 1021 (Ind. Ct. App. 2014).

37. Id. at 1022 .

38. Id.

39. Id. at 1026 .

40. Id. at 1024 .

41. Id.

42. Good v. Wells Fargo Bank, N.A., 18 N.E.3d 618, 619 (Ind. Ct. App. 2014).

43. Id. at 620 . 
first, the holder of the note was entitled to enforce it and, second, the person who "controlled" the note within the meaning of $\S 7021$ was its holder. ${ }^{44}$ But the court concluded Wells Fargo had not shown it controlled the note for purposes of $\S$ 7021 , and therefore had not established its status as holder for purposes of the UCC..$^{45}$

In One West Bank, FSB v. Jarvis, the trial court held a bank had breached the parties' loan modification agreement by failing to remove negative references on the mortgagors' credit report and committing other errors. ${ }^{46}$ These errors were so severe, in the trial court's opinion, it held the bank in contempt and levied a $\$ 100,000$ sanction. $^{47}$

Noting the bank had not challenged the determination it was in contempt, the court examined the record and found there was ample evidence from which the trial court could have inferred the mortgagors were subjected to compensable inconvenience and frustration, and the award of $\$ 100,000.00$ as sanctions was within its discretion. ${ }^{48}$

Lewallen Revocable Trust v. Fifth Third Mortgage Co., involved some real estate owned by a family subject to a Fifth Third mortgage ${ }^{49}$ A family trust, of which the mother was a trustee, owned $50 \%$ of the property. ${ }^{50}$ The only child, a son, owned the other half. ${ }^{51}$ The parents had a life estate in the property. ${ }^{52}$

At some point, Fifth Third refinanced the loan. ${ }^{53}$ When the bank rounded up the signatures on the new mortgage, it failed to obtain the signature of the son. ${ }^{54}$

The note and mortgage went into default shortly after the parents died in $2010 .^{55}$ The bank foreclosed on the mortgage in $2011 .^{56}$

The Indiana Court of Appeals held that, although the bank was equitably subrogated to the rights of the first mortgagee, the failure to secure the son's signature on the new mortgage rendered the mortgage void with respect to the son's one-half interest in the property. ${ }^{57}$ The court affirmed the trial court's decree of foreclosure in favor of the bank, but only with respect to the one-half

44. Id. at 623 .

45. Id. at 624 .

46. One W. Bank, FSB v. Jarvis, No. 45A03-1501-MF-1, 2015 WL 3871054, at*1 (Ind. Ct. App. June 23, 2015) (unpublished disposition).

47. $I d$. at $* 2$.

48. Id. at *3-4.

49. Lewallen Revocable Tr. v. Fifth Third Mortg. Co., No. 15A01-1409-MF-396, 2015 WL 3500462, at*1 (Ind. Ct. App. June 2, 2015) (unpublished disposition).

50. Id.

51. $I d$.

52. Id.

53. Id. at $* 8$.

54. Id.

55. Id.

56. Id.

57. Id. at *9. 
interest held by the trust. ${ }^{58}$

\section{Business LAW}

In the area of business law, the survey period saw enactment of a statute authorizing an entirely new business entity - the Benefit Corporation-and presented a number of cases addressing relations between and among owners of closely held business organizations.

\section{A. The New "B-Corp" ("Benefit Corporation") Statute}

A century ago, it was ultra vires for a corporation to take a charitable or beneficent act that did not further the interests of the stockholders. ${ }^{59}$ The leading exemplar of this principle is Dodge v. Ford Motor Co.,${ }^{60}$ the 1919 case in which the Michigan Supreme Court slapped Henry Ford around for trying to run the Ford Motor Company with "philanthropic and altruistic" motives. ${ }^{61}$ A more nuanced view of corporate purpose emerged as the century progressed. ${ }^{62}$ Today, the Indiana Business Corporation Law ("BCL") expressly authorizes corporations to "make donations for the public welfare or for charitable, scientific, or educational purposes" and also "make payments or donations, or do any other act, not inconsistent with law, that furthers the business and affairs of the corporation." ${ }^{63}$

Beyond engaging in acts benefiting society that are ancillary to its mission, the last several decades have seen enterprises emerge that use business methods to achieve a primary social or environmental mission. ${ }^{64}$ Two professors at the Indiana University Robert H. McKinney School of Law, Vice Dean Antony Page and Robert A. Katz, have been keen observers of such "social enterprises," which have been organized as either nonprofit or for-profit entities. ${ }^{65}$ In 2016, the Indiana General Assembly enacted, and Governor Mike Pence signed into law,

58. Id.

59. See, e.g., Dodge v. Ford Motor Co., 170 N.W. 668, 684 (Mich. 1919).

60. Id.

61. Id.

62. See, e.g., A. P. Smith Mfg. Co. v. Barlow, 98 A.2d 581, 582 (N.J. 1953) (finding no fault with a corporation making a contribution to the annual fund of Princeton University).

63. IND. CoDE § 23-1-22-2(13), (15) (2016); see also id. § 23-1-35-1(d) (a director may, "in considering the best interests of a corporation, consider the effects of any action on shareholders, employees, suppliers, and customers of the corporation, and communities in which offices or other facilities of the corporation are located, and any other factors the director considers pertinent.").

64. See generally Antony Page \& Robert A. Katz, Is Social Enterprise the New Corporate Social Responsibility?, 34 Seattle U. L. ReV. 1351 (2011).

65. See Antony Page, New Corporate Forms and Green Business, 37 WM. \& MARY EnVTL. L. \& Pol'y Rev. 347 (2013); Robert A. Katz \& Antony Page, Sustainable Business, 62 EMORY L.J. 851 (2013); Page \& Katz, supra note 63; Robert A. Katz \& Antony Page, The Role of Social Enterprise, 35 VT. L. ReV. 59 (2010) [hereinafter Katz \& Page, Social Enterprise]. 
legislation authorizing a new form of corporation, ${ }^{66}$ which must have as one of its purposes the creation of "general public benefit." Such new entities are called "benefit corporations" and have been nick-named "B-corps." ${ }^{97}$ The legislation took effect January 1, 2016. ${ }^{68}$

State Representative Casey Cox, the principal sponsor of Indiana's B-corp law, explained,

When businesses register as a benefit corporation, it enables the corporation to put its social mission of giving back alongside profitseeking considerations. Benefit corporations expand the obligation of boards, requiring them to consider environmental and social factors, as well as the financial interest of shareholders. This gives directors and officers the legal protection to pursue a mission and consider the impact of their business toward the public good. ${ }^{69}$

Representative Cox believes the "legislation is a great step toward retaining and attracting creative entrepreneurs and job creators to Indiana." ${ }^{, 70}$

It is beyond the scope of this survey article to describe the provisions of the new benefit corporation article of the Indiana Code in complete detail. What follows are what the author considers to be the new statute's most important provisions.

First, as suggested above, a benefit corporation must have as one of its purposes "creating general public benefit." "General public benefit" means "a material positive impact on society and the environment, taken as a whole, assessed against a third party standard, from the business and operations of a benefit corporation." ${ }^{72}$ The articles of incorporation filed with the Secretary of State must state the corporation is a benefit corporation. ${ }^{73}$

In addition, a benefit corporation's articles can also identify one or more specific public benefits that it is the purpose of the corporation to create. ${ }^{74}$ "Specific public benefit" for this purpose "means a benefit that serves (1) one or more public welfare, religious, charitable, scientific, literary, or educational purposes; or (2) other purposes or benefits beyond the strict interests of the shareholders." ${ }^{\prime 75}$

66. IND. CODE $\S \S 23-1.3-1-1$ to -10-6 (2016), enacted by Pub. L. No. 93-2015, § 3 (2015).

67. See generally Christopher Lacovara, Strange Creatures: A Hybrid Approach to Fiduciary Duty in Benefit Corporations, 2011 Colum. Bus. L. REv. 815 (2011).

68. IND. CoDE $\S 23-1.3-1-1$.

69. Casey Cox, Benefit Corporations, Ind. House Representatives Republican Caucus (Dec. 21, 2015), http://www.indianahouserepublicans.com/news/enews/benefit-corporations [https://perma.cc/ST88-PLGK].

70. Id.

71. IND. CODE $\S 23-1.3-4-1$.

72. Id. $\S 23-1.3-2-7$.

73. Id. § 23-1.3-3-1.

74. Id. $\S 23-1.3-4-2(\mathrm{a})$.

75. Id. $\S 23-1.3-2-10$. The statute provides that "specific public benefit" includes: 
Second, although a corporation is entitled to register as a benefit corporation with the Secretary of State, the statute makes clear the State itself makes no judgment as to whether the corporation actually provides a general public benefit or specific public benefit. ${ }^{76}$

Third, one of the unique features of a benefit corporation is the Board of Directors must have a member who is designated the "benefit director." 77 This director, who must meet certain explicit standards of independence, has responsibility for preparing an "annual benefit report to shareholders" as to whether the corporation has acted in accordance with this general benefit purpose and any specific public benefit purpose during the preceding year. ${ }^{78}$

Fourth, as suggested by Representative Cox's comments quoted above, the statute is quite explicit in providing protection to the directors and officers of benefit corporations against a claim that consideration of a general public benefit or a specific public benefit violates any duty of a director or officer. ${ }^{79}$ In addition, directors and officers are also provided protection against a claim the corporation failed to pursue or create a general public benefit or a specific public benefit. ${ }^{80}$ The statute also provides directors and officers have no duty to a person who is a beneficiary of the general public benefit purpose or a specific public benefit purpose of the corporation arising from the status of the person is a beneficiary. ${ }^{81}$

On the other hand, standing is conferred on certain entities and individuals ${ }^{82}$

(1) providing low income or underserved individuals or communities with beneficial products or services; (2) promoting economic opportunity for individuals or communities beyond the creation of jobs in the normal course of business; (3) protecting or restoring the environment; (4) Improving human health; (5) promoting the arts, sciences, or advancement of knowledge; (6) increasing the flow of capital to entities with a purpose to benefit society or the environment; and (7) conferring any other particular benefit on society or the environment.

Id.

76. Indiana Code section 23-1.3-3-2(a)(2) requires the articles of an existing corporation that becomes a benefit corporation contain a statement reading:

By enacting this article, the State of Indiana does not endorse any particular benefit corporation, or approve or disapprove any of the purposes of a benefit corporation or any claimed general public benefit or specific public benefit, and no inference should be drawn from the acceptance of any filings with respect to a benefit corporation under IC $23-1.3$, that the benefit corporation has or will in fact provide any general public benefit or specific public benefit.

Id. $\S 23-1.3-3-2(\mathrm{a})(2)$.

77. Id. § 23-1.3-6-1.

78. Id. $\S 23-1.3-6-3(1)$. The report must also include certain information on director compliance with the statue. Id. $\S 23-1.3-6-3(2),(3)$.

79. Id. § 23-1.3-5-3(1).

80. Id. $\S 23-1.3-5-3(2)$.

81. Id. § 23-1.3-5-4.

82. See id. § 23-1.3-2-10(b); see also id. § 23-1.3-9-3 ("A benefit enforcement proceeding may be commenced or maintained only: (1) directly by the benefit corporation; or (2) derivatively 
to file a "benefit enforcement proceeding" for the "failure of a benefit corporation to pursue or create [] [a] general public benefit[,] [] or a specific public benefit," or "a violation of any obligation, duty, or standard of conduct under this article." $" 83$

Lastly, the new benefit corporation statute incorporates the provisions of the BCL by reference as default provisions. ${ }^{84}$ It also contains explicit provisions governing the conversion of a corporation organized under the BCL into a benefit corporation; ${ }^{85}$ the merger of a corporation organized under the BCL into a benefit corporation, ${ }^{86}$ and the termination of a corporation's status as a benefit corporation by amendment of the articles of incorporation, ${ }^{87}$ merger,${ }^{88}$ or sale of all, or substantially all assets. ${ }^{89}$ In general, these provisions require a $90 \%$ vote of the shareholders (or holders of other interests) entitled to vote on the action. ${ }^{90}$

An argument can be made that the powers and protections conferred on Bcorps by the new statute were already available under the BCL. However, there is no question other states use B-corps and Indiana needed to get with the social enterprise movement in a visible way. Representative Cox deserves congratulations and appreciation for his effective leadership in bringing the new statute to fruition.

\section{B. Relationships Among Shareholders, Partners, or Members}

In Rueth Development Co. v. Powers-Rueth \& Associates, the sole general partner of a limited partnership executed a contract to sell a country club owned by the partnership to the country club's members. ${ }^{91}$ A limited partner sought to enjoin the sale. ${ }^{92}$

The court examined the partnership agreement and found the general partner had power under the agreement to convey partnership property, and as such, could only be found to have breached his fiduciary duty upon a determination he

in accordance with IC 23-1-32 by: (A) a person or group of persons that owned at least two percent $(2 \%)$ of the total number of shares of a class or series outstanding at the time of the act or omission complained of; (B) a director; (C) a person or group of persons that owned at least five percent $(5 \%)$ of the outstanding equity interests in an entity of which the benefit corporation is a subsidiary at the time of the act or omission complained of; or (D) other persons as specified in the benefit corporation's articles of incorporation or bylaws.").

83. Id. $\S 23-1.3-2-5$.

84. Id. $\S 23-1.3-1-4$.

85. Id. $\S 23-1.3-3-2$.

86. Id. $\S 23-1.3-3-3$.

87. Id. $\S 23-1.3-3-4$.

88. Id. § 23-1.3-3-5.

89. Id. $\S 23-1.3-3-6$.

90. Id. § 23-1.3-2-9.

91. Rueth Dev. Co. v. Powers-Rueth \& Assoc., No.45A05-1402-PL-80, 2014 WL 5776214, at *2 (Ind. Ct. App. 2014) (unpublished disposition), trans. denied, 30 N.E.3d 1229 (Ind. 2015).

92. Id. 
had acted fraudulently, in bad faith, or with gross negligence..$^{93}$ The court then examined the designated evidence and concluded there was no genuine issue of material fact that the general partner was guilty of so acting. ${ }^{94}$

What made this case interesting was the dissenting limited partner also sought to assert claims of breach of fiduciary duty on the part of other limited partners. ${ }^{95}$ The question of whether a limited partner owes a fiduciary duty to other limited partners appears to be one of first impression under Indiana law, but there is authority for the plaintiffs' position in other jurisdictions, including Illinois, Kansas, and Delaware. ${ }^{96}$

The court held there is no authority under Indiana law that limited partners owe a fiduciary duty to the partnership or to other limited partners and rejected the plaintiff's request to adopt the position of the various other jurisdictions. ${ }^{97}$

Smith $v$. Taulman ${ }^{98}$ falls into the "no good deed goes unpunished" category. Taulman and Smith owned $52 \%$ and $48 \%$, respectively, of the shares of a corporation. ${ }^{99}$ Taulman was the corporation's president and active in its management; Smith was vice president and had few specific duties. ${ }^{100}$

In December 2009, Taulman convened a meeting with Smith and several high-ranking employees to discuss the future of the corporation. ${ }^{101}$ After Taulman and the employees described the company's dire situation, all agreed to purchase new shares except Smith, whose holdings were thereby diluted to about $10 \% .{ }^{102}$ The business subsequently recovered. ${ }^{103}$ In July 2010, Taulman fired Smith for failure to work. ${ }^{104}$

Smith then sued Taulman and the other employees for breaching fiduciary duties Smith alleged they owed him and for committing fraud at the December 2009 meeting. ${ }^{105}$ Why? Because Smith alleged Taulman and the others had not adequately informed Smith of the company's business outlook for 2010. ${ }^{106}$

Said differently, Smith argued he had agreed to a dilution of his interest because the others had poormouthed the company's prospects when in fact those prospects were quite good. ${ }^{107}$ The author's reading of the court's opinion suggests this was a company in severe financial distress, but Taulman and the

93. $I d$. at $* 15$.

94. Id. at *18.

95. Id. at *17.

96. Id. at *18.

97. Id.

98. Smith v. Taulman, 20 N.E.3d 555 (Ind. Ct. App. 2014).

99. Id. at 556 .

100. Id. at 560 .

101. Id. at 561 .

102. Id. at 562 .

103. Id. at 555.

104. Id. at 562 .

105. Id.

106. Id. at 555.

107. See id. 
other executives refused to give up the ship and were eventually able to right it. ${ }^{108}$

A key aspect of this case is its holding on fiduciary duty. Although Taulman had a fiduciary duty to Smith as a fellow shareholder in a closely held corporation, the other employees did not. This was because they only became shareholders after the meeting. ${ }^{109}$

Smith made another set of claims worthy of mention. A number of entities and individuals with affiliations to Taulman had business relationships with the company. ${ }^{110}$ Smith contended those entities and individuals had derivative liability to the corporation because the contracts were for less than fair market value or constituted "ghost employment" arrangements. ${ }^{111}$ Here, the court examined the designated evidence and concluded the entities and individuals failed to designate evidence to negate at least one element of Smith's shareholder derivative claims. ${ }^{112}$ A word to the wise for when a closely held business organization enters into contracts or employment arrangements with affiliates: such transactions must meet the strict requirements of adherence to fiduciary duty.

The subject of derivative litigation leads nicely to TP Orthodontics, Inc. $v$. Kesling. ${ }^{113}$ Although litigation involving the use of special litigation committees (SLCs) under the BCL attracts attention when utilized by publicly held corporations, ${ }^{114}$ SLCs are equally available to closely held corporations. ${ }^{115}$ This case shows their use by, and utility to, the latter.

When three shareholders who collectively owned $11 \%$ of a closely held corporation sued, the board of directors appointed an CLC to investigate the claims. ${ }^{116}$ The SLC report was heavily redacted. ${ }^{117}$ The shareholders then asked the court for access to the unredacted report to challenge the SLC's investigation as not having been made in good faith. ${ }^{118}$

This put the Indiana Supreme Court in a tricky position. The SLC technique certainly strengthens management's hand - and was designed to do so. ${ }^{119}$ But does it go too far to allow management to use the SLC strategy and then redact the SLC's report so severely the complaining shareholders are in no position to challenge it?

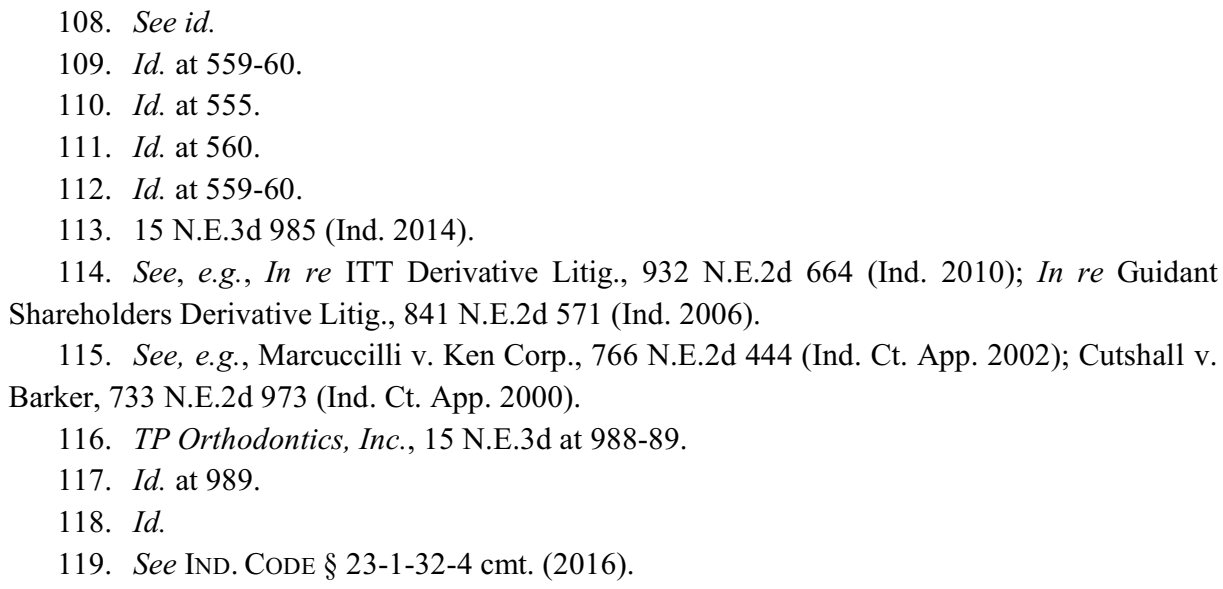


In an opinion by Justice Steven H. David, the court explicated Indiana's "strongly pro-management version of the business judgment rule" 120 and the SLC process as a "manifestation of the business judgment rule." ${ }^{21}$ Because a SLC's findings are conclusive so long as the committee is disinterested (not at issue here) and the investigation is made in good faith, derivative plaintiffs are entitled to evidence of an SLC's methodology. ${ }^{122}$ However, the court concluded even though the entire SLC report could be relevant to that issue, it could also contain privileged information precluding disclosure. ${ }^{123}$ The court struck a balance by declaring SLC reports are presumptively to be disclosed. It then mandated in camera review by the trial court to resolve this conflict. ${ }^{124}$

Starting with its enactment in 1986, the BCL has been noted for the protections it provides corporate officers and directors. ${ }^{125}$ But the court's opinion in TP Orthodontics is consistent with at least three other decisions of the court that were also unwilling to turn a complete blind eye to the rights of shareholders. ${ }^{126}$ The court certainly recognized the protections the Indiana General Assembly has provided directors and officers but the court also assumed, at minimum, the common-law fiduciary duty that owners of closely held business organizations owe to each other is not displaced by the BCL.

\section{Agency}

Indiana Restorative Dentistry, P.C. v. Laven Insurance Agency, Inc. ${ }^{127}$ was discussed in last year's survey as a decision of the Indiana Court of Appeals that was on its way to the Indiana Supreme Court. ${ }^{128}$

After Indiana Restorative Dentistry, P.C. ("IRD”), sustained a fire loss in excess of its insurance coverage, IRD sued Laven, the insurance agency through which it had purchased coverage, to recover the uninsured losses resulting from the fire. ${ }^{129}$ The trial court had entered summary judgment for the insurance

120. TP Orthodontics, Inc., 15 N.E.3d at 991 (quoting G \& N Aircraft, Inc. v. Boehm, 743 N.E.2d 227, 238 (Ind. 2001)).

121. $I d$.

122. Id. at 992 .

123. Id. at 993 .

124. $I d$. at 998 .

125. See, e.g., IND. CodE § 23-1-35-1(f) (2016); CTS Corp. v. Dynamics Corp. of Am., 481 U.S. 69, 95 (1987) (Scalia, J., concurring in part and concurring in the judgment); Edwin J. Simcox, The Indiana Business Corporation Law: Tool for Flexibility, Simplicity and Uniformity, 20 InD. L. REV. 119, 129-131 (1987).

126. See G \& N Aircraft, Inc. v. Boehm, 743 N.E.2d 227 (Ind. 2001); Melrose v. Capitol City Motor Lodge, Inc., 705 N.E.2d 985 (Ind. 1998); Fleming v. Int'1 Pizza Supply Corp., 707 N.E.2d 1033 (Ind. Ct. App. 1999).

127. 27 N.E.3d 260 (Ind. 2015).

128. See generally Sullivan, supra note 32.

129. Ind. Restorative Dentistry, 27 N.E.3d at 262. 
agency, but the court of appeals reversed. ${ }^{130}$

There were two issues here: whether the insurance agency had a duty to advise IRD about its insurance coverage and whether the insurance agency was under a contractual duty to provide insurance that would have fully covered the fire losses. ${ }^{131}$

The Indiana Supreme Court held the designated evidence supported conflicting inferences on whether the parties enjoyed a special relationship that created a duty to advise. ${ }^{132}$ However, the record did not show any discussion between the parties supporting an implied contract to procure full coverage, much less a meeting of the minds. ${ }^{133}$ As such, summary judgment for the insurance agency on that issue was sustained. ${ }^{134}$

A second agency case is Bunger $v$. Demming, which is sort of the quintessential Bloomington case. ${ }^{135}$ On behalf of an individual named Sheree Demming, a realtor named Cheryl Underwood regularly inquired as to the availability for purchase of certain residential properties; from 2002 until 2007, the owner declined to sell. ${ }^{136}$ In 2007, Underwood bought the properties for herself. ${ }^{137}$ At issue was whether Underwood had an agency relationship with Demming; the trial court held there was. ${ }^{138}$ The court of appeals examined the evidence and concluded the trial court's determination that Underwood and Demming had an agency relationship was not clearly erroneous. ${ }^{139}$

\section{CONTRACt LaW}

\section{A. Back to Basics}

During the survey period, there were two cases reviewing some of the basics of contract law: a statute of limitations case and a statute of frauds case. ${ }^{140}$

The statute of limitations case is Folkening v. Van Petten where Megan Van Petten sued Chad Folkening to enforce a settlement agreement under which she was to have been paid $\$ 175,000$ for her stock in a corporation and paid in full on

130. Id. at 263 .

131. Id. at 262 .

132. $I d$.

133. Id.

134. Id.

135. See generally Bunger v. Demming, 40 N.E.3d 887 (Ind. Ct. App.), trans. denied sub nom., Underwood v. Demming, 40 N.E.3d 858 (Ind. 2015).

136. Id. at 891-92.

137. Id. at 892 .

138. Id. at 893 .

139. Id. at 904 .

140. See Folkening v. Van Petten, 22 N.E.3d 818 (Ind. Ct. App. 2014), trans. denied, 29 N.E.3d 124 (Ind. 2015); see also Huber v. Hamilton, 33 N.E.3d 1116 (Ind. Ct. App.), trans. denied, 41 N.E.3d 690 (Ind. 2015). 
a mortgage on certain property in which she owned a $50 \%$ interest. ${ }^{141}$

The lawsuit was filed more than six years after execution. ${ }^{142}$ So, was Van Petten's claim subject to the six-year limitation period for actions on "written contracts for the payment of money" or the ten-year limitation period that applies to actions on written contracts "other than those for the payment of money[?]"143

The Indiana Court of Appeals examined the settlement agreement and concluded the substance of the action was breach of contract and more than just the payment of money. ${ }^{144}$ The court cited promissory notes, bills of exchange, and checks as examples of "agreements to pay money to another party; they are not agreements to pay money in exchange for something else, such as goods, services, real property, or stock shares such as those at issue [in this case]."145

Huber v. Hamilton is the statute of frauds case where Roger Hamilton sold commercial real estate to Terry Huber on a land contract. ${ }^{146}$ The contract was in writing and contained a balloon payment. ${ }^{147}$ As the due date for the balloon payment approached, the parties orally agreed to extend the term. ${ }^{148}$ In subsequent litigation, each party presented a different version of their oral agreement. ${ }^{149}$

The court examined the language of and policies supporting the statute of frauds and held because the land contract was required to be in writing, any modification to it also had to be in writing. ${ }^{150}$ The oral agreement was held unenforceable and the parties' rights and obligations were held to be governed by the original written land contract. ${ }^{151}$

\section{B. Employment Contracts}

This survey period saw quite a few employment contracts. What follows is a quick listing of contending parties and the result; for the most part, the employer won.

In Prescott v. St. Mary of the Woods College, a dismissed a tenured professor sued alleging breach of contract; the employer prevailed. ${ }^{152}$

In Hewitt v. Westfield Washington School Corp., a school corporation terminated an elementary school principal upon discovering his intimate

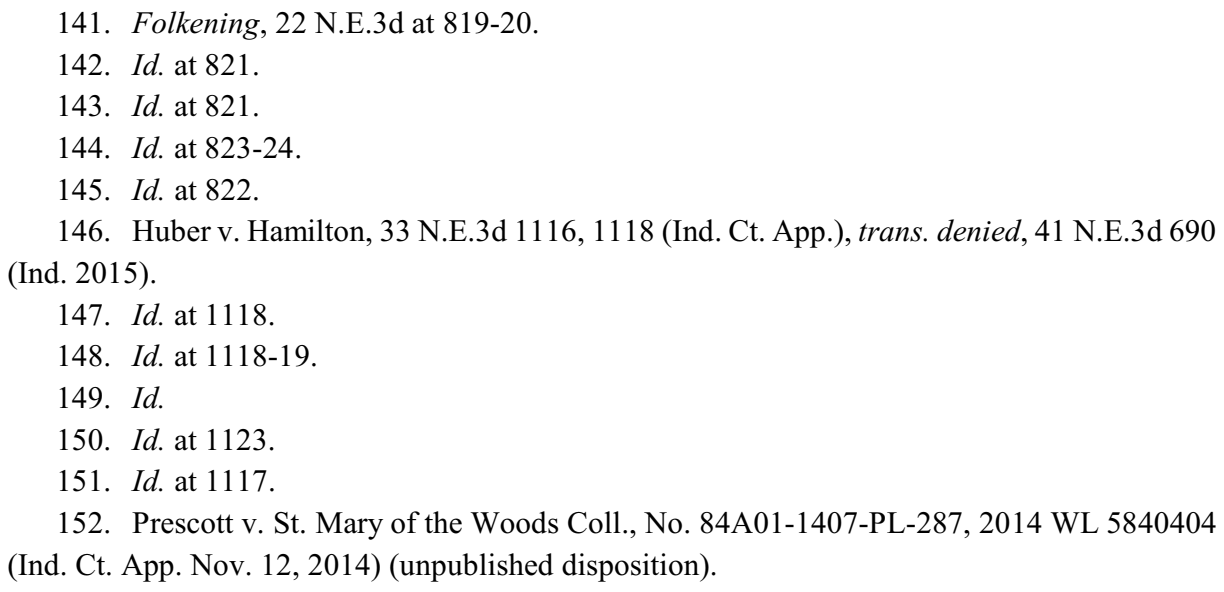


relationship with a subordinate teacher. ${ }^{153}$ The trial court affirmed the dismissal, but the Indiana Court of Appeals reversed. ${ }^{154}$ Following the completion of the survey period, the Indiana Supreme Court reinstated the dismissal. ${ }^{155}$

In Duty v. Boys \& Girls Club of Porter County, an employee reported improper financial practices on the part of employer's president. ${ }^{156}$ The president's employment ended in April 2013, and the employee was terminated in July 2013. ${ }^{157}$ The employee challenged the dismissal, arguing she was fired for whistle blowing. The employer prevailed. ${ }^{158}$

In Matthies v. First Presbyterian Church of Greensburg Indiana, Inc., a pastor sued a church alleging violations of the Indiana Wage Claims Statute and Indiana common law following his discharge before the expiration of a three-year employment contract. ${ }^{159}$ The employer won. ${ }^{160}$

Lastly, in AM Gen., LLC v. Armour, Armour, the retired president, CEO, and chairman of AM General, was entitled to payments under an employment agreement. ${ }^{161}$ During 2012, the company sent Armour a promissory note purporting to encompass the company's remaining obligations under the employment agreement but, in fact, including many new terms and conditions. ${ }^{162}$ Armour refused to accept the note and demanded payment of the outstanding amount owed him. ${ }^{163}$ The trial court ruled for the employee, but the court of appeals reversed. ${ }^{164}$ Following the completion of the survey period, the Indiana Supreme Court reinstated the trial court's ruling for the employee. ${ }^{165}$

It is interesting to see in two of these five cases, the supreme court granted transfer and reversed the court of appeals: one in which the court of appeals ruled for the employee, the other in which the court of appeals ruled for the employer. ${ }^{166}$ In both cases, the court of appeals had reversed the trial court. ${ }^{167}$

153. Hewitt v. Westfield Wash. Sch. Corp., 24 N.E.3d 459 (Ind. Ct. App., 2014), rev'd, 46 N.E.3d 425 (Ind. 2015).

154. Hewitt v. Westfield Wash. Sch. Corp., 46 N.E.3d 425 (Ind. 2015).

155. Id.

156. Duty v. Boys \& Girls Club of Porter Cty., 23 N.E.3d 768, 770 (Ind. Ct. App. 2014).

157. Id.

158. Id. at 775-76.

159. Matthies v. First Presbyterian Church of Greensburg Ind., Inc., 28 N.E.3d 1109, 111 (Ind. Ct. App. 2015).

160. Id.

161. AM Gen., LLC v. Armour, 27 N.E.3d 817 (Ind. Ct. App.), rev'd, 46 N.E.3d 436 (Ind. 2015).

162. Id. at 817-19.

163. Id.

164. Id. at 820 .

165. Am Gen. LLC v. Armour, 46 N.E.3d 436 (Ind. 2015).

166. See Hewitt v. Westfield Wash. Sch. Corp., 46 N.E.3d 425 (Ind. 2015); see also AM Gen., LLC, 27 N.E.3d 817.

167. $I d$. 


\section{Leases}

During the past year, there were two cases involving commercial leases that came to different results on almost the same facts. ${ }^{168}$

Both cases involve commercial leases with renewal options. ${ }^{169}$ In both cases, the tenants held over for a certain period of time but never indicated to the landlord they were exercising their renewal option. ${ }^{170}$ After holding over for a certain number of months, the respective tenants notified their landlords they were vacating the premises. ${ }^{171}$ In each case, the landlord took the position the tenant had, by the mere fact of holding over, exercised the renewal option and was liable for rent for the balance of the renewal term. ${ }^{172}$

The cases were Pearman v. Jackson, in which the tenants prevailed, ${ }^{173}$ and Norris Ave. Professional Building Partnership v. Coordinated Health, LLC, in which the landlord won. ${ }^{174}$

In Pearman, at the end of the lease term, tenants did not notify landlord they were exercising the renewal option. ${ }^{175}$ The tenants held over for three months and then notified the landlord they no longer wished to hold over on a monthly basis and vacated the premises. ${ }^{176}$

The Indiana Court of Appeals examined the landlord's claim that he had unilaterally waived the written notice of renewal requirement and that the tenants' continued payment of rent established the option to renew the lease term was in fact exercised. ${ }^{177}$ The court held the purpose of the requirement of written notice to renew was to differentiate between renewal and a holdover from monthto-month and as such, the tenants' payment of rent and continued occupation of the leased premises standing alone was insufficient to establish they had exercised the option to renew under both case law and the explicit terms of the lease. ${ }^{178}$

In Norris Ave, there were similar facts: at the end of the initial two-year term, tenant did not notify landlord it was exercising its option but in fact held over for the full five years. ${ }^{179}$ At the end of that five-year period, tenant again did

168. See Pearman v. Jackson, 25 N.E.3d 772 (Ind. Ct. App. 2015); see also Norris Ave. Prof'1 Bldg. P'ship v. Coordinated Health, LLC, 28 N.E.3d 296 (Ind. Ct. App.), trans. denied, 34 N.E.3d 684 (Ind. 2015).

169. See generally Pearman, 25 N.E.3d 772; see also Norris Ave., 28 N.E.3d 296.

170. See Pearman, 25 N.E.3d 772; see also Norris Ave., 28 N.E.3d 296.

171. See Pearman, 25 N.E.3d 772; see also Norris Ave., 28 N.E.3d 296.

172. See Pearman, 25 N.E.3d 772; see also Norris Ave., 28 N.E.3d 296.

173. See Pearman, 25 N.E.3d 772

174. See Norris Ave., 28 N.E.3d 296.

175. Pearman, 25 N.E.3d at $774-75$.

176. Id. at 774 .

177. Id. at 779 .

178. Id.

179. See Norris Ave., 28 N.E.3d at 297-98. 
not notify landlord it was exercising its option but continued to hold over. ${ }^{180}$ Approximately two years later, tenant surrendered the premises, having paid all rents due up to that time. ${ }^{181}$

Here, the court of appeals held the notice provision in the lease was a condition precedent to tenant's exercise of either option term but the condition existed for the benefit of the landlord and the landlord had the right to waive tenant's compliance with the condition. ${ }^{182}$

The court held the landlord did waive compliance by accepting tenant's increased rent payments - the fact that tenant paid increased rent being a critical distinction. ${ }^{183}$ Transfer was denied in this case by a vote of three to two, with Chief Justice Rush and Justice Brent E. Dickson voting to grant. ${ }^{184}$

\section{Insurance Contracts}

Because there is a separate survey of insurance law, the discussion here will focus only on several insurance cases with particularly interesting contract issues. These include two similar cases involving subrogation.

In $L B M$ Realty, $L L C v$. Mannia, after a residential tenant caused a fire in an apartment building, the landlord's insurer filed an insurance subrogation action against the tenant. ${ }^{185}$ The tenant argued that a landlord's insurer is precluded from filing a subrogation claim against a negligent tenant. ${ }^{186}$

Now the law handles this issue in three different ways: no-subrogation (or implied co-insured) because the tenant is presumed to be a co-insured under the landlord's insurance policy; pro-subrogation; or case-by-case, in which the availability of subrogation is based on the reasonable expectations of the parties under the facts of each case. ${ }^{187}$

The court adopted the case-by-case approach, acknowledging although the case-by-case approach is said to provide less predictability than either the pro or no-subrogation approaches, "this approach best effectuates the intent of the parties by simply enforcing the terms of their lease."

The next case is Indiana Farm Bureau Insurance Co. v. Wood Shield, LLC. ${ }^{189}$ In Indiana Farm Bureau, a fire caused substantial damage in office space Wood

180. Id. at 298 .

181. Id.

182. Id. at 302 .

183. Id. at 303 .

184. See Norris Ave. Prof'l Bldg. P'ship v. Coordinated Health, LLC, 34 N.E.3d 684 (Ind. 2015).

185. LBM Realty, LLC v. Mannia, 19 N.E.3d 379, 381 (Ind. Ct. App. 2014).

186. Id. at 382 .

187. Id. at 383 .

188. Id. at 394.

189. No. 29A02-1403-PL-136, 2014 WL 4783259 (Ind. Ct. App. Sept. 25, 2014) (unpublished disposition). 
Shield leased from Real Estate Technologies, Inc. ${ }^{190}$ Landlord's fire insurance carrier tendered insurance proceeds in the amount of the damage and then, as landlord's subrogee, sought damages from Wood Shield. ${ }^{191}$ The court of appeals examined the designated evidence and concluded a dispute as to which risks the parties intended to include within the risks required to be insured against created genuine issues of material fact precluding summary judgment. ${ }^{192}$

Is there a difference between LBM Realty and this Indiana Farm Bureau case? The author believes the cases to be consistent. Implicit in Indiana Farm Bureau's holding that coverage could not be determined as a matter of summary judgment is that a case-by-case determination precludes pronouncements as a matter of law, although the court did not use the language of the first opinion. ${ }^{193}$

\section{E. Environmental Remediation Claims}

There were at least three high-stakes environmental remediation claims that were the subject of court of appeals opinions during the last year. They are really too complicated to get into in detail but worthy of mention as examples of how such disputes get to court.

Travelers Casualty \& Surety Co. v. Maplehurst Farms, Inc. ${ }^{194}$ arose out of a December 2002 settlement agreement between Maplehurst and IDEM under which Maplehurst assumed responsibility to remediate certain environmental contamination to IDEM's satisfaction. ${ }^{195}$ Maplehurst did not seek coverage from its carrier until after entering into the settlement agreement. ${ }^{196}$

The question was whether Maplehurst's expenditures made after the insurer received notice but attributable to the settlement agreement were "incurred" prior to the date of notice. ${ }^{197}$ The court of appeals held they were and denied coverage. ${ }^{198}$

In FLM, LLC v. Cincinnati Insurance Co., ${ }^{199}$ a company called IRI had stored sand retrieved from a Chrysler foundry on property it leased from FLM in Indianapolis. ${ }^{200}$ Chrysler stopped paying IRI, which consequently went out of

190. Id. at *1.

191. Id.

192. Id. at *3.

193. Id.

194. Travelers Cas. \& Sur. Co. v. Maplehurst Farms, Inc., 18 N.E.3d 311, 312-13 (Ind. Ct. App. 2014), trans. denied sub nom., Travelers Cas. \& Sur. Co. of Am., 29 N.E.3d 1274 (Ind. 2015).

195. Travelers Cas. \& Sur. Co. v. Maplehurst Farms, Inc., 18 N.E.3d 311, 312-13 (Ind. Ct. App. 2014), trans. denied sub nom., Travelers Cas. \& Sur. Co. of Am., 29 N.E.3d 1274 (Ind. 2015).

196. Id. at $312-13,317$.

197. Id. at 317 .

198. Id. at 317-18.

199. FLM, LLC v. Cincinnati Ins. Co., 24 N.E.3d 444, 447 (Ind. Ct. App. 2014), aff'd on reh'g, 27 N.E.3d 1141 (Ind. Ct. App. 2015), trans. denied, 34 N.E.3d 251 (Ind. 2015).

200. Id. 
business and abandoned 100,000 tons of sand on the FLM property. ${ }^{201}$ IDEM determined the sand violated environmental regulations and the City of Indianapolis found the sand violated the municipal code. ${ }^{202}$

At issue was whether property damage coverage was available for FLM's claims against IRI under a CGL policy IRI had with Cincinnati Insurance; ${ }^{203}$ whether the CGL policy allowed separate $\$ 1$ million limits for personal injury and property damage; and whether the policy's intentional injury exclusion applied. ${ }^{204}$ The court of appeals found in favor of the policyholder. ${ }^{205}$

In Thomson, Inc. v. XL Insurance America, Inc., Thomson sought coverage from insurer for costs incurred by Thomson related to the investigation and cleanup of environmentally contaminated sites in Taiwan and Ohio. ${ }^{206}$ The issue was whether the so-called "known loss" doctrine prohibited Thomson from recovering from insurer. ${ }^{207}$

If an insured has actual knowledge a loss has occurred, is occurring, or is substantially certain to occur on or before the effective date of the policy, "the known loss doctrine bars coverage." ${ }^{\circ 28}$ The coverage here first became effective on January $1,2000{ }^{209}$

As to the Taiwan site, the court of appeals found that "Thomson had actual knowledge of the contamination of the soil and groundwater on the Taiwan Plant long before January 1, 2000," 210 but that "the legal liability to remediate that contamination ... did not exist until the legislature in Taiwan enacted the legislation providing for retroactive liability for remediating environmental contamination in 2000." 211

As to the Ohio site, the insurance company argued that because Thomson had agreed in 1994 to investigate potential contamination and to implement any remedial actions that Ohio's EPA might order, the alleged loss was "known," thereby precluding coverage. However, the court of appeals found a genuine issue of material fact as to Thomson's knowledge, precluding application of the known loss doctrine. ${ }^{212}$

Transfer was sought in all three of these cases, but the Indiana Supreme Court declined to take any of them on. ${ }^{213}$

201. Id.

202. FLM, LLC v. Cincinnati Ins. Co., 973 N.E.2d 1167 (Ind. Ct. App. 2012).

203. 24 N.E. $3 d$ at 448.

204. Id. at 456 .

205. Id. at 458 .

206. See generally Thomson, Inc. v. XL Ins. Am., Inc., 22 N.E.3d 809 (Ind. Ct. App. 2014), trans. denied, 34 N.E.3d 251 (Ind. 2015).

207. Id. at 810 .

208. Id. at 814 .

209. Id. at 813 .

210. Id. at 815 .

211. Id.

212. Id. at 816 .

213. See Thomson, Inc. v. XL Ins. Am., Inc., 34 N.E.3d 251 (Ind. 2015); FLM, LLC v. 


\section{Is There a Statute on That?}

The author of this Article is in his fourth year of teaching at the Indiana University Robert H. McKinney School of Law after nineteen years as a Justice on the Indiana Supreme Court. It is likely his students would report-because he repeats this a lot - that some of his most embarrassing moments as a practicing lawyer and as a judge (and even now as a teacher) occurred when, upon being presented with a legal question, problem or issue, he attempted to devise a common law solution - only to learn later there was a statute that provides the answer.

And so he has taught his students that when they are presented with a legal question, problem, or issue, they should always ask, "Is there a statute on that?"

There were several cases during the survey period where the author was surprised to learn the outcome was governed by statute, not common law.

Bunger v. Demming, the agency case from Bloomington, required the court to deal not only with common-law agency principles, but also to interpret a statute, Indiana Code section 25-34.1-10-9.5(a), which provides no agency relationship exists where a realtor is "merely assisting the individual as a customer without compensation." 214 The court decided the statutory claim by concluding the trial court's finding that Underwood provided services beyond merely "assisting [Demming] as a customer without compensation" was not clearly erroneous. ${ }^{215}$

Paul v. Stone Artisans, Ltd., was an effort by a contractor to foreclose on a mechanic's lien after a homeowner failed to pay the final installment on contract for kitchen countertops and backsplashes. ${ }^{216}$ The homeowner argued she and the contractor had never formed a contract and even if they did, it did not comply with the requirements of a statute, the Indiana Home Improvement Contract Act (HICA). ${ }^{217}$ The court of appeals concluded although two of the requirements of the HICA were not met, the trial court had been correct to conclude the contract substantially complied with HICA and its purposes. ${ }^{218}$

In Young v. Hood's Gardens, Inc., Hood's Gardens contracted with Craig Mead to remove a large tree for a fixed price of $\$ 600$; Mead was permitted to keep the wood, which he intended to sell as firewood. ${ }^{219}$ A statute-a provision of the worker's compensation statute, Indiana Code section 22-3-214(b) - imposes certain obligations on any person "contracting for the performance of any work exceeding one thousand dollars $(\$ 1,000)$ in value by

Cincinnati Ins. Co., 34 N.E.3d 251 (Ind. 2015); Travelers Cas. \& Sur. Co. of Am., 29 N.E.3d 1274 (Ind. 2015).

214. Bunger v. Demming, 40 N.E.3d 887, 896 (Ind. Ct. App.), trans. denied sub nom., Underwood v. Demming, 40 N.E.3d 858 (Ind. 2015).

215. Id. at 897.

216. Paul v. Stone Artisans, Ltd., 20 N.E.3d 883, 885 (Ind. Ct. App. 2014).

217. Id. at $885-86$.

218. Id. at 889 .

219. Young v. Hood's Gardens, Inc., 24 N.E.3d 421, 423 (Ind. 2015). 
a contractor." ${ }^{220}$ The court had to decide whether Hood Gardens' contract with Mead triggered these obligations - and concluded it was a question of fact, not amenable for resolution on summary judgment. ${ }^{22}$

These cases serve as apt reminders that when confronted with a legal question or problem or issue, the careful lawyer, judge, and professor always asks, "Is there a statute on that?"

220. Id. at 424 .

221. Id. at 426 . 